\title{
Influence of Bloomberg's Investor Sentiment Index: Evidence from European Union Financial Sector
}

\author{
Mariano González-Sánchez ${ }^{1, *(D)}$ and M. Encina Morales de Vega ${ }^{2}$ (D) \\ 1 Department of Business and Accounting, Universidad Nacional de Educación a Distancia (UNED), \\ Paseo Senda del Rey, 11, 28040 Madrid, Spain \\ 2 Department of Business, Universidad San Pablo CEU, Julián Romea, 23, 28003 Madrid, Spain; \\ memorales@ceu.es \\ * Correspondence: mariano.gonzalez@cee.uned.es
}

Citation: González-Sánchez, M.; Morales de Vega, M.E. Influence of Bloomberg's Investor Sentiment Index: Evidence from European Union Financial Sector. Mathematics 2021, 9, 297. https://doi.org/ 10.3390/math9040297

Academic Editor: Miltiadis Chalikias Received: 8 January 2021

Accepted: 30 January 2021

Published: 3 February 2021

Publisher's Note: MDPI stays neutral with regard to jurisdictional claims in published maps and institutional affiliations.

Copyright: (c) 2021 by the authors. Licensee MDPI, Basel, Switzerland. This article is an open access article distributed under the terms and conditions of the Creative Commons Attribution (CC BY) license (https:/ / creativecommons.org/licenses/by/ $4.0 /)$.

\begin{abstract}
A part of the financial literature has attempted to explain idiosyncratic asset shocks through investor behavior in response to company news and events. As a result, there has been an increase in the development of different investor sentiment measurements. This paper analyses whether the Bloomberg investor sentiment index has a causal relationship with the abnormal returns and volume shocks of major European Union (EU) financial companies through a sample of 85 financial institutions over 4 years (2014-2018) on a daily basis. The i.i.d. shocks are obtained from a factorial asset pricing model and ARMA-GARCH-type process; then we checked whether there is both individual and joint causality between the standardized residuals. The results show that the explanatory capacity of the shocks of the firm Bloomberg sentiment index is low, although there is empirical evidence that the effects correspond more to the situation of the financial subsector (banks, real estate, financial services and insurance) than to the company itself, with which we conclude that the sentiment index analyzed reflects a sectorial effect more than individual one.
\end{abstract}

Keywords: investor sentiment; idiosyncratic shocks; financial institutions; market risk

\section{Introduction}

The Investor Sentiment Index is a way of measuring the reaction of investors to the news published about events in companies. As stated by [1] the presence of investor sentiment pushes asset prices away from the equilibrium level justified by underlying fundamentals. For that reason, its construction and analysis have become increasingly important in the literature, leading to the application of different methodologies and approaches.

Initially, work on investor sentiment was based on news about companies without differentiating good from bad news [2]. Later the literature identified an asymmetry between the effects of negative and positive news [3-15].

A temporal asymmetry was also identified when differentiating between times of recession and of expansion [16-18]. In addition, its effect on volatility and trading volume has also been analyzed, distinguishing between small and institutional investors [3,9,16,19-21].

In view of this increased interest in the explanatory capacity of investor sentiment, numerous empirical studies have developed investor sentiment indexes, although many of them have not corroborated their effectiveness outside the study sample [8,9,16,22]. Also, there is no consensus on how to build those indexes and which variables or information to include [23]. As a result, some information providers and financial institutions have attempted to respond to demand by producing reports and even developing their own investor sentiment indexes (both Reuters and Bloomberg have such indexes).

Another aspect related to this variety of applied methodologies has been to consider or not an asset valuation model when quantifying this index of investor sentiment. There is extensive financial literature on asset pricing that attempts to adjust the linear crosssectional relationship between excess asset returns over the risk-free rate and exposure to 
risk factors [24-27]. However, in some cases, the 5 results are not as significant as might be expected. So-called abnormal returns arise as a difference between the observed and expected returns based on the pricing model used. In this way, there is a line of financial research that attempts to explain these idiosyncratic shocks or abnormal returns. One of the possible explanations for these shocks is how investors react to news published about the companies, which can be identified as investor sentiment.

On the other hand, the financial literature has found that the economic and regulatory environment affects performance as a result of the institutional quality and corporate governance of companies [28], the level of legal institutions and economic development [29], the level of integration and development of financial markets $[11,30]$ and cultural differences [31]. The sample selection is, for this reason, a factor that can condition the results of the study on the relationship between investor sentiment and financial asset price behavior.

Our aim is to test the usefulness of such investor sentiment indexes (in particular, the Bloomberg investor sentiment index) offered by financial information providers to explain idiosyncratic return and volume shocks.

Related to our scope, reference [32] measures the effectiveness in predicting the Reuters sentiment index with respect to the Dow Jones Industrial Index, concluding that that negative Reuters sentiment shows more predictive power than positive Reuters sentiment.

Regarding the importance of sample selection stated previously, our empirical study is focused on a group of listed financial companies (same industry and regulation) in the European Union (same socio-economic environment). This sample has been chosen because this specific sector has suffered a large number of mergers and restructurings in recent years and also it has been greatly weakened during the 2008 financial crisis along with an increase in regulation. In this sense, we found very little literature focused on analyzing the financial sector. Reference [33], for example, built a sentiment index for the Chinese financial market and find that it does not always influence the 45 quoted companies' price. Reference [34] found a significant and negative relationship (asymmetric) between news sentiment (obtained from Thomson Reuters News Analytics) and changes in credit risk of major international banks (measured by CDS spreads). More specifically, for the Spanish banking system, reference [35] analyzed the relationship between stakeholders, Twitter posts and investors reactions in the market and find there is a positive impact on investor's decisions. Reference [36] analyzed the tone of news published on reputational events in a sample of European, American and Canadian financial institutions, concluding that a negative tone increases the implicit risk of default, while a more neutral tone decreases it.

Our results show that the Bloomberg investor sentiment index has a low causal relationship with the abnormal returns and volume shocks of major EU financial companies but the empirical evidence indicates that the effects correspond more to the situation of the financial subsector (banks, real estate, financial services and insurance) than to the company itself, with which our contribution is that the sentiment index analyzed reflects a sectorial effect more than individual one.

The rest of this paper is organized as follows-Section 2 reviews the literature, describes the methodology followed in the study and presents the sample uses; Section 3 shows the results obtained; and Section 4 explains the main conclusions of the study.

\section{Materials and Methods}

\subsection{Background}

The main research of the financial literature seems to show a consensus on the existence of a relationship between investor sentiment and the financial markets $[8,20]$. The market variable usually analyzed is the return on assets but the effect on trading volume $[37,38]$ and volatility $[17,31,39]$ has also been studied.

In contrast, there is no such consensus on how to measure investor sentiment (see [40] for an in-depth literature review and [15] for an analysis related to the financial sector). A first approach to investor sentiment is through building indexes that incorporate market 
variables (among others, $[4,8,41]$ ). A major problem with these is that they can include other types of information unrelated to investor perceptions.

A second approach is to develop indexes using investor surveys [42]. There are several relevant indexes for the US market: University of Michigan Consumer Sentiment Index (a monthly index calculated from a consumer confidence survey of a random group of five hundred American households) [10,30,43-47]; the American Association of Individual Investor sentiment survey (an index that provides weekly information on the bullish, bearish or neutral perception of a pool of financial market surveys over the next six months) [6,19,48-52]; and the Investor Intelligence and Daily Sentiment Index (an index that determines the balance between bull and bear investors) [53]. In the case of the European Union, the European Commission's monthly consumer confidence indicator has been used [54].

In general, these empirical studies using surveys find relationships between the sentiment indexes and market variables, but, like the first of the approaches, it is not without its drawbacks, like its low observation frequency (monthly or quarterly) and, like [40] point out, these rates are less reliable when the non-response rate in surveys is high or the incentive to answer honestly is low.

A third approach is to build sentiment indexes from information provided by the media. These indexes have several advantages, such as the increase in the frequency of data compared to the previous ones (daily instead of monthly or quarterly in surveys), data are cheaper to obtain and they can be applied to a less restricted number of stocks. Within this approach, three different forms of application can be distinguished depending on where the news is from-first, news published in specialized financial media, for example, [9] uses the Wall Street Journal and [16] the New York Times; secondly, those obtained from an internet search engine, for example, [42] use Google keywords, while [55] use certain publications on Google, although in this approach, the results should be interpreted with some degree of caution due to the lack of transparency about how the data were created and uncertainty about the reason for the search [56]; and finally, the use of news from social media such as Facebook, Twitter or LiveJournal [57,58]. In general, these empirical studies show that there is a relationship between investor sentiment as measured by media information and market variables. It should also be noted that this relationship is more important in the case of companies whose shares show extreme returns or higher risk [10,11,41,59-62]. But, like with the other two approaches, this one also presents problems since the relationship between investor sentiment and market returns has a different impact and direction depending on the source of the information used.

As the use of investor sentiment indexes has become more widespread, empirical studies on this issue have begun to use high-frequency data, that is, daily and intraday data $[20,40,63]$, as opposed to less frequent data, such as monthly or weekly data from surveys [64-66]. The frequency effect of the data is relevant as indicated by [67] since while the relationship between short-term sentiment and portfolio returns is positive, in the long term the relationship is the opposite.

At the same time as the investor sentiment indexes, the literature has developed that attempts to explain return on assets through textual analysis of the news $[13,68]$. There is no clear evidence of its explanatory capacity, since there are papers that argue it has greater potential than sentiment indexes [39,69-71] but we also find papers arguing otherwise, as a consequence of the different linguistic perception of each investor, the market where the news is from, the asymmetry between words with negative and positive connotations, the language in which the news is given and the analysis of words out of context $[14,19,32,33,35,36,62,66,71,72]$.

A final key element is the size of the investor whose sentiment is analyzed [37]. There is no consensus: some studies find there is a relationship between small investor sentiment and market prices $[7,28,30,43-45,48,50,73-75]$ and others $[6,54,70,76]$ conclude that there is no significant relationship between retail investor sentiment and market returns, even 
finding that the explanatory power is in the opposite direction, that is, returns and volatility variations affect sentiment, not the other way around.

The role of institutional investor sentiment is not clear in the literature either [77], since while some empirical studies show that this sentiment explains the behavior of market prices $[45,74,78]$, others conclude that its usefulness is limited or non-existent in explaining the market returns of assets [6]. Some studies [53] show that although experienced analysts give greater importance to their own information and less to public information when faced with negative news, they tend to follow the herd behavior to a greater extent, while those others who operate for investment banks or trade in high volumes do so to a lesser extent. Investor sentiment is not a thermometer unrelated to the investor's size and knowledge or expertise.

In summary, based on the literature reviewed, we can group the empirical studies together by two fundamental characteristics: on the one hand, those papers that do not consider an asset valuation model to measure the relationship between investor sentiment and market returns of assets $[12,17,28,37,79,80]$, versus those who do $[7,9,11,62,64,66,67,81,82]$; and on the other, studies that develop their own sentiment indexes $[11,35,41,71,82]$ versus those using indexes developed by specialized investors or economic agents $[9,36,64,82-84]$.

With regard to the first of these characteristics, it is clear that, to validate the effects of any event on the financial variables, the empirical study must be carried out by adjusting an asset valuation model, that is, once the systematic risks arising from the risk factors have been excluded. It will be the idiosyncratic shocks that might contain information on investor sentiment about each particular asset; otherwise the investor's sentiment will not be about a particular asset but about the market in general. Reference [85], for example, is a sample of empirical work on the effect of investor sentiment on market indexes or portfolios rather than on individual stocks: the analysis is, logically, less complex, as the shocks are smaller than if the study were conducted individually by companies. Our work is included in this group of studies.

As for the second characteristic, building an ad-hoc index for an empirical paper is obviously not exempt from a certain degree of subjectivity. The trend, for that reason, is to use information directly extracted from specialized media or with high data traffic (Twitter and Google) or Reuters sentiment index [32]. In the case of the data used in this paper, Ref. [86] explains that the sentiment index has been put together taking into account the publication of news and tweets considered relevant to a given company and giving it a numerical valuation of investor sentiment. Bloomberg assigns a positive, negative or neutral valuation depending on how the published information would affect an investor with a long position, that is, if she/he would react by taking a bullish, bearish or neutral stance. This assessment is then introduced into automatic learning models, resulting in the Bloomberg sentiment index. The Bloomberg sentiment index is constructed in an aggregate way with all the news published daily for a company, unlike the Thompson Reuters News Analytics index (TRNA).

\subsection{Econometric Model for Analyzing Causality}

In financial institutions, our field of study, it should be noted that [82] use the factorial model of [25] and information from the Wall Street Journal to examine the effect of media sentiment on the market valuation of banks injected with liquidity by the US government within the Capital Purchase Program (CPP).

In our case, we use [24-27] five-factor model (we have opted for a factorial model, although others could be used (such as a hidden factors model), because it allows us to obtain in a simple way the idiosyncratic effect and abnormal returns from factors widely used in the financial literature). In addition, the data used are presented in daily frequency, since, as noted above, the use of high-frequency data represents more reliably the influence of the sentiment index on financial variables, unlike [32] which uses monthly frequency data to measure the impact of the index provided by Reuters on the Dow Jones. This type 
of database does not take into account heteroscedasticity problems that, on the contrary, can be corrected with data on a daily basis.

In addition, some empirical works, which analyzed high frequency data (daily), consider the usual statistical properties of the series like heteroscedasticity [52], an issue we also consider. In a first stage we extract the idiosyncratic shocks of the daily performance, the daily variations of the log-volume and the log-average of Bloomberg's investor sentiment index, unlike [80].

The multivariate VAR-GARCH (Vector Autoregression with Multivariate-GARCH) methodology allows to jointly estimate the causality in mean and variance for a set of assets but it has some drawbacks: such as computational complexity, that happens when the number of assets increases; the difficulty to estimate returns that have a different univariate heteroscedastic behavior and multivariate $\mathrm{GARCH}$ process does not guarantee stationary univariate variance; specifying dependence on the multivariate GARCH is hard for nonnormality series. Thus, if each return has different marginal probability distributions, then the estimation of the conditional distribution is difficult, with the consequent effect on the asymptotic behavior of the maximum likelihood estimator. Meanwhile, in the case of the CCF (Cross Correlation Function) methodology, it proves to be robust to non-symmetric and leptokurtic errors, although there are some disadvantages: the conditionality is estimated by pairs, so for a set of assets, it does not allow to determine the common origin of the effects; the joint estimation of causality in mean and variance is not possible by this methodology, since the results of the second are conditioned by the first; the causality in variance is sensitive to structural breaks in the parameters.

In short, neither methodologies outperform the other, both require a two-stage estimation and have different computational intensity and sensitivity to the stylized facts of returns. In this context, this paper chooses the CCF methodology for its robustness against the stylized facts. Thus, we apply a methodology to test the causality in mean and variance similar to [87].

We define $r_{i, t}$ as the excess of the daily return on asset $i$ on day $t$ over the risk-free rate on the same day $\left(R f_{t}\right)$, where the daily return is the first difference in the logarithm of the daily price. $F_{m, t}$ is the value of systemic risk factor $m$ on day $t$. The asset pricing model is expressed as:

$$
\begin{gathered}
r_{i, t}=\beta_{0, i}+\sum_{m=1}^{M} \beta_{m, i} \cdot F_{m, t}+u_{i, t} \\
u_{i, t} \sim \operatorname{iid}\left(0, \sigma_{i, t}^{2}\right),
\end{gathered}
$$

where $u_{i, t}$ is the abnormal result with non-constant variance, so to obtain the i.i.d. shocks we model the variance based on a $\operatorname{GARCH}(1,1)$ process:

$$
\sigma_{i, t}^{2}=\delta_{0, i}+\delta_{1, i} \cdot u_{i, t-1}^{2}+\delta_{2, i} \cdot \sigma_{i, t-1}^{2} .
$$

Then, the idiosyncratic shock is $z_{i, t}=\frac{u_{i, t}}{\sigma_{i, t}} \sim \operatorname{iid}(0,1)$.

Additionally and in order to contrast the robustness of the proposed factorial pricing model (model of observable factors), we check its goodness of fit with respect to a model of hidden or latent factors. For that, following [88], we use PCA (principal component analysis) to compare the results of latent (hidden) factors pricing model with observable factorial pricing model. The latent factors $(F)$ are estimate as: $F=r \cdot \Lambda \cdot\left(\Lambda^{\mathrm{T}} \cdot \Lambda\right)^{-1}$, where $r$ are excess return on assets and $\Lambda$ are eigenvectors of the largest (L) eigenvalues (at 95\% explanatory level). Then, we estimate regression:

$$
r_{i, t}=\alpha_{0}+\sum_{j=1}^{L} \beta_{j} \cdot F_{j, t}+\xi_{i, t}
$$


To compare these approaches (latent vs. observed factors) we calculate two indicators of accuracy level: first, root of mean alphas $\left(R M S_{-} \alpha=\sqrt{\frac{1}{N} \sum_{i=1}^{N} \alpha_{i}^{2}}\right)$, note that higher values of RMS_ $\alpha$ show higher anomalies and therefore, a worse accuracy level of pricing. Second, we estimate the mean of asset idiosyncratic variances $\left(\sigma_{\xi}=\sqrt{\frac{1}{N} \sum_{i=1}^{N} \sigma_{\xi_{i}}^{2}}\right)$, so, if $\sigma_{\xi}$ hidden factor model is higher than observed factor model then, hidden factor model would have a lower explanatory level of asset return than observed factor model, since systematic risk of hidden factors would be lower than observed factors.

For volume $\left(V_{i, t}\right)$, we estimate the daily variations $\left(v_{i, t}=\ln \frac{V_{i, t}}{V_{i, t-1}}\right)$ and the relative change in the volume of the EUROSTOXX-50 $\left(v_{x, t}=\ln \frac{V_{x, t}}{V_{x, t-1}}\right)$, so the idiosyncratic shock is extracted from the standardized residuals of an $\operatorname{ARMA}(\mathrm{P}, \mathrm{Q})-\mathrm{GARCH}(1,1)$ process:

$$
\begin{gathered}
v_{i, t}=\alpha_{0, i}+\alpha_{x, i} \cdot v_{x, t}+\sum_{p=1}^{P} \alpha_{p, i} \cdot v_{i, t-p}+\sum_{q=1}^{Q} \alpha_{P+q, i} \cdot e_{i, t-q}+e_{i, t} \\
\sigma_{v, i, t}^{2}=\delta_{0, i}+\delta_{1, i} \cdot e_{i, t-1}^{2}+\delta_{2, i} \cdot \sigma_{v, i, t-1}^{2} .
\end{gathered}
$$

The idiosyncratic shock of the volume is $z v_{i, t}=\frac{e_{i, t}}{\sigma_{v, i, t}} \sim \operatorname{iid}(0,1)$.

Finally, we define the daily log-difference of the Bloomberg sentiment index as $b_{i, t}=$ $\ln \frac{B_{i, t}}{B_{i, t-1}}$, which we model as an ARMA(P,Q)-GARCH $(1,1)$ process:

$$
\begin{gathered}
b_{i, t}=\omega_{0, i}+\sum_{p=1}^{P} \omega_{p, i} \cdot b_{i, t-p}+\sum_{q=1}^{Q} \omega_{P+q, i} \cdot \phi_{i, t-q}+\phi_{i, t} . \\
\sigma_{b, i, t}^{2}=\delta_{0, i}+\delta_{1, i} \cdot \phi_{i, t-1}^{2}+\delta_{2, i} \cdot \sigma_{b, i, t-1}^{2} \cdot
\end{gathered} .
$$

And finally, the idiosyncratic shock of the variations in the investor sentiment index would be $z b_{i, t}=\frac{\phi_{i, t}}{\sigma_{i, t}} \sim \operatorname{iid}(0,1)$.

Once the idiosyncratic shocks have been obtained, there are now different analysis possibilities. First, since the systematic effects have been eliminated, it would be logical to expect that each sentiment index would influence the abnormal returns and volume shocks of the stock itself. If we measure this influence in terms of Granger causality and, given the statistical properties of the shocks, for each company we can estimate the following linear regression by Ordinary Least Squared (OLS) for each asset $i$ :

$$
y_{i, t}=\lambda_{0}+\sum_{h=1}^{H} \lambda_{h} \cdot z b_{i, t-h}+\psi_{i, t},
$$

where $y_{t}$ is both the abnormal returns $\left(z_{t}\right)$ and volume shock $\left(z v_{t}\right)$.

As there could be an interrelation between companies in the same subsector, we carry out a joint estimate by subsector by means of simultaneous equations applying the Full Information Maximum Likelihood (FIML) method, then the expression to be estimated for a subsector $s$, with $N$ firms, is:

$$
\left[\begin{array}{c}
y_{1, t} \\
\vdots \\
y_{N, t}
\end{array}\right]=\left[\begin{array}{c}
\rho_{1,0} \\
\vdots \\
\rho_{N, 0}
\end{array}\right]+\left[\begin{array}{ccc}
\rho_{1,1} & \cdots & \rho_{1, J} \\
\vdots & \ddots & \vdots \\
\rho_{N, 1} & \cdots & \rho_{N, J}
\end{array}\right] \cdot\left[\begin{array}{ccc}
z b_{1, t-1} & \cdots & z b_{1, t-J} \\
\vdots & \ddots & \vdots \\
z b_{N, t-1} & \cdots & z b_{N, t-J}
\end{array}\right]+\left[\begin{array}{c}
\varepsilon_{1, t} \\
\vdots \\
\varepsilon_{N, t}
\end{array}\right] .
$$

If the results of estimate Expression-(7) showed companies with significant parameters that, when estimating the Expression-(6) were not, then this would indicate that there is a contagion effect between shocks of companies from the same subsector and, consequently, we would analyzed the common effect of the shocks of the investor sentiment index differentiating by subsectors.

For that, we define a dummy $\left(D_{s, i}\right)$ which will be worth 1 if the institution $i$ belongs to the subsector $s$ (banking, real estate, financial services and insurance) and zero otherwise. To corroborate the asymmetrical effect of the sentiment index found in the literature reviewed, we define a dummy assigned a 1 if on day $(t-j)$ the original variable (excess returns or relative change in volume) was negative, otherwise it will be zero, so for each institution we will obtain $D_{r, i}$ and $D_{v, i}$. This way we avoid possible problems of endogeneity, since the 
value of the dummies does not depend on the sign of the shocks of the sentiment index. Finally, we estimate the following panel data model:

$$
y_{i, t}=\gamma_{0}+\sum_{h=1}^{H} \gamma_{h}^{+} \cdot\left[D_{s, i} \cdot\left(1-D_{y, i}\right) \cdot z b_{i, t-h}\right]+\sum_{h=1}^{H} \gamma_{h}^{-} \cdot\left[D_{s, i} \cdot D_{y, i} \cdot z b_{i, t-h}\right]+\mu_{i, t} .
$$

From Expression-(7), we obtain the effect of the shocks of the investor sentiment index according to the subsector over the abnormal returns and the shocks of the first difference of the volume logarithm, respectively. This effect will be obtained by differentiating whether the returns or volume changes were positive or negative in significant delays, that is, we check whether the effect is asymmetrical. The residuals $\left(\mu_{i, t}\right)$ may reflect the fixed or random effects of the model depending on the specific test for their selection (Hausman test).

\subsection{Sample of Data}

The sample used covers listed financial institutions in the EU. The period chosen runs from 1 April 2014 to 30 March 2018, on a daily basis. The sample has been subdivided into banks, financial services, insurance and real estate, according to the ICB (Industry Classification Benchmark) provided by Bloomberg. Each subsample is composed of the most capitalized (high market value) and largest (measured by assets) companies, that is, the set of companies that exceed $95 \%$ of the total subsector market and asset values at the same time. There were 85 institutions listed in Appendix A and their subsectors are: banking (32), real estate (16), financial services (29) and insurance (8). Price, volume (including EUROSTOXX-50) and investor sentiment index data are obtained from Bloomberg, while data on systemic factors are from the French data web (http:/ / mba.tuck.dartmouth.edu/ pages/faculty/ken.french/Data_Library/f-f_5developed.html).

\section{Results}

\subsection{Statistics}

First, we show in Table 1 the statistics characteristics of the sample.

Table 1 shows in two panels the statistical summary of factors and daily returns, volume changes and investor sentiment index variations companies by subsectors. Panel A displays the statistics for the systemic factors included in Expression-(1). Panel B displays the statistics for the entire sample, showing the results for each variable by quartiles only (the rest of the statistics are available upon request.).

The results in Table 1 show that all series are stationary. In most cases, so-called stylized facts can be observed, including non-normality, autocorrelation of series in levels and squared and conditional heteroscedasticity. The model proposed to obtain the independent shocks is therefore justified.

\subsection{Adjustment of Econometric Models for Shock Extraction}

First, we estimate econometric models for excess returns, changes of volume and sentiment Bloomberg index.

From Table 2 we verify that: regarding daily returns, we find that considering a factorial asset valuation model is essential to extract shocks; for volume and sentiment indices, we find that they follow both autoregressive and moving average processes and, finally, we note that in most variables show heteroscedasticity. In summary, not considering these statistical and financial characteristics of the data could mean that the results obtained are biased. We then check that the shocks defined above as standardized residuals of the models estimated above are i.i.d. The statistical summary is shown in Table 3. 
Table 1. Summary statistics.

\begin{tabular}{|c|c|c|c|c|c|c|c|c|c|c|c|c|c|}
\hline \multicolumn{14}{|c|}{ Panel A. Statistical Summary of Systemic Factors } \\
\hline Factors & \#obs & Min & Mean & $\operatorname{Max}$ & std.dev & Skewness & \multicolumn{2}{|c|}{ Excess Kurtosis } & Jarque-Bera & $\mathrm{ARCH}$ & Box-Pierce & $\begin{array}{c}\text { Box-Pierce } \\
\text { Squared }\end{array}$ & ADF \\
\hline Mkt-Rf & 1044 & -0.0879 & 0.0002 & 0.0356 & 0.0091 & -1.001 & \multicolumn{2}{|c|}{9.913} & 4448.8 & 24.97 & 19.88 & 166.66 & -17.164 \\
\hline var_VOL Eurostoxx & 1044 & -1.3493 & -0.0019 & 1.2421 & 0.2792 & -0.039 & \multicolumn{2}{|c|}{2.042} & 181.650 & 6.87 & 127.22 & 33.00 & -18.085 \\
\hline SMB & 1044 & -0.1610 & 0.0001 & 0.0185 & 0.0043 & -0.086 & \multicolumn{2}{|c|}{1.634} & 117.390 & 9.69 & 12.38 & 63.93 & -14.861 \\
\hline HML & 1044 & -0.0207 & -0.0001 & 0.0175 & 0.0041 & 0.244 & \multicolumn{2}{|c|}{1.669} & 135.910 & 6.22 & 4.90 & 39.58 & -14.284 \\
\hline RMW & 1044 & -0.0151 & 0.0002 & 0.0161 & 0.0028 & -0.290 & \multicolumn{2}{|c|}{2.290} & 240.810 & 4.45 & 12.45 & 27.14 & -13.736 \\
\hline CMA & 1044 & -0.0084 & -0.3487 & 0.0107 & 0.0025 & 0.225 & \multicolumn{2}{|c|}{0.984} & 50.926 & 3.57 & 2.54 & 19.09 & -14.274 \\
\hline \multicolumn{14}{|c|}{ Panel B. Statistical Summary for Companies } \\
\hline \multirow{5}{*}{ Return-Rf } & Min. & 1044 & -1.1982 & -0.0070 & 0.0527 & 0.0157 & -8.302 & 1.363 & 82.008 & 0.01 & 1.95 & 0.06 & -18.761 \\
\hline & Q1 & 1044 & -0.2744 & -0.0008 & 0.0930 & 0.0197 & -0.889 & 3.973 & 698.010 & 4.03 & 8.18 & 24.84 & -15.982 \\
\hline & Q2 & 1044 & -0.2260 & -0.0002 & 0.1187 & 0.0223 & -0.384 & 6.779 & 2078.2 & 8.23 & 12.03 & 54.54 & -15.583 \\
\hline & Q3 & 1044 & -0.1591 & 0.0001 & 0.1706 & 0.0341 & -0.065 & 11.668 & 5957.5 & 16.07 & 19.33 & 89.22 & -14.956 \\
\hline & Max & 1044 & -0.0771 & 0.0010 & 0.4940 & 0.0704 & 2.124 & 173.650 & $1,323.70$ & 116.30 & 183.25 & 393.12 & -13.161 \\
\hline \multirow{4}{*}{ Var. Volume } & Min. & 1044 & -9.4171 & -0.0016 & 1.4442 & 0.3364 & -0.576 & 0.395 & -0.5757 & 0.49 & 83.20 & 2.55 & -24.6407 \\
\hline & Q1 & 1044 & -2.8156 & -0.0006 & 1.9098 & 0.3924 & 0.053 & 1.306 & 0.0531 & 9.14 & 123.64 & 45.22 & -22.1418 \\
\hline & Q3 & 1044 & -1.8124 & 0.0004 & 3.2382 & 0.6015 & 0.286 & 4.429 & 0.2863 & 25.53 & 186.76 & 122.20 & -20.4301 \\
\hline & $\hat{\operatorname{Max}}$ & 1044 & -1.1510 & 0.0063 & 11.0450 & 1.8481 & 0.855 & 139.740 & 0.8554 & 143.44 & 260.26 & 400.12 & -18.7247 \\
\hline \multirow{5}{*}{ Bloomberg index } & Min. & 1044 & -1.0000 & -0.0442 & 0.0884 & 0.1180 & -5.051 & -1.492 & -5.0508 & 5.94 & 70.63 & 32.17 & -12.8279 \\
\hline & Q1 & 1044 & -0.9911 & 0.0572 & 0.8579 & 0.2625 & -0.623 & 0.504 & -0.6232 & 77.91 & 627.47 & 464.13 & -9.6259 \\
\hline & Q2 & 1044 & -0.9733 & 0.0969 & 0.9218 & 0.2707 & -0.274 & 1.074 & -0.2736 & 307.85 & 1940.30 & 1791.53 & -7.1652 \\
\hline & Q3 & 1044 & -0.8682 & 0.1277 & 0.9624 & 0.3005 & 0.041 & 2.066 & 0.0414 & 1247.53 & 3901.94 & 3646.93 & -4.8387 \\
\hline & Max & 1044 & -0.6633 & 0.1958 & 0.9984 & 0.3544 & 3.724 & 30.047 & 3.7242 & 36079 & 5086.58 & 5131.81 & -3.12748 \\
\hline
\end{tabular}

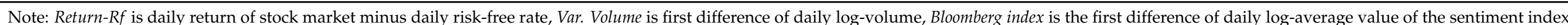

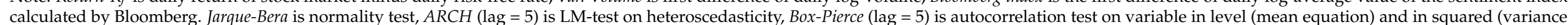

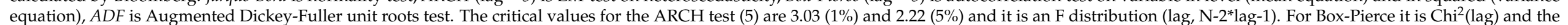
critical values are $15.09(1 \%)$ and $11.07(5 \%)$. 
Table 2. Estimate of the models to obtain the shocks.

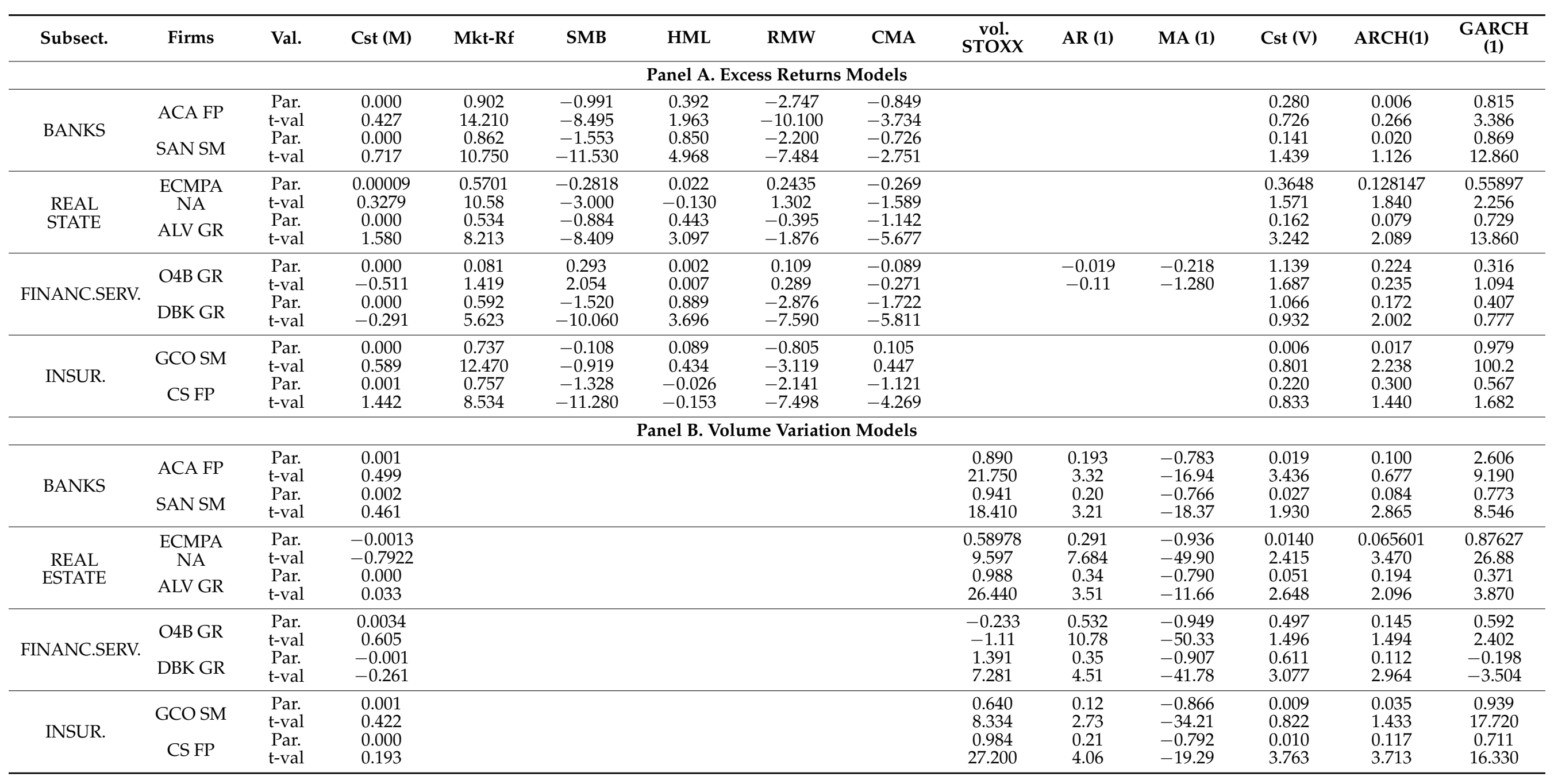


Table 2. Cont.

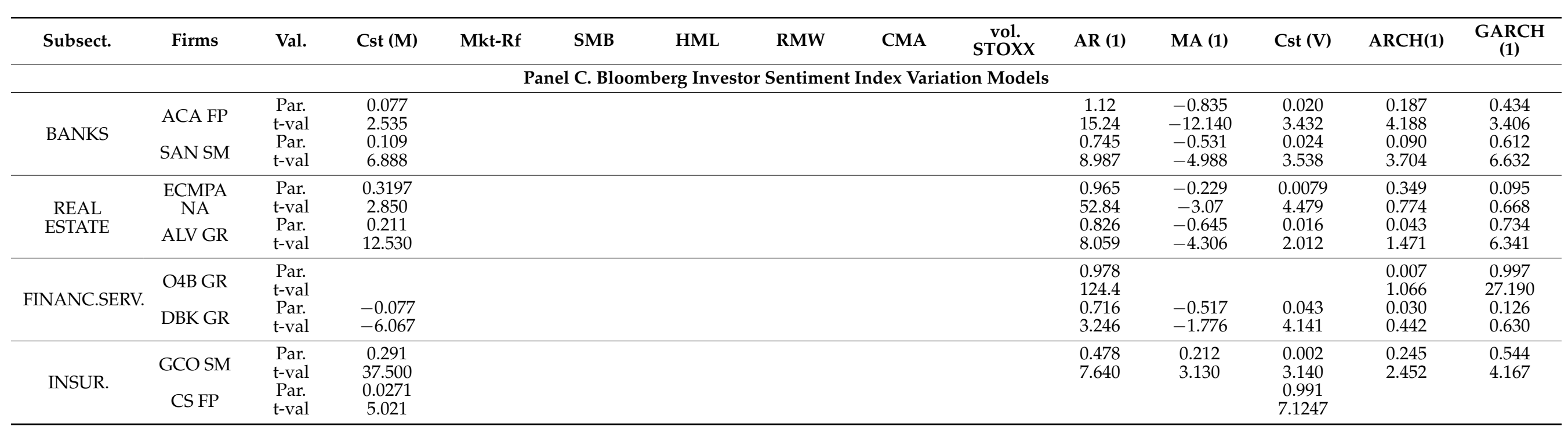


Table 3. Statistical summary of standardized shocks.

\begin{tabular}{|c|c|c|c|c|c|c|c|c|c|}
\hline Subsector & Firms & \#obs & Value & Mean & std.dev & Jarque-Bera & ARCH & Box-Pierce & $\begin{array}{c}\text { Box-Pierce } \\
\text { Squared }\end{array}$ \\
\hline \multicolumn{10}{|c|}{ Panel A. Statistical Summary for Excess Returns Models } \\
\hline \multirow{4}{*}{ BANKS } & \multirow{2}{*}{ ACA FP } & 1044 & \multirow{4}{*}{$\begin{array}{c}\text { Test } \\
p \text {-value } \\
\text { Test } \\
p \text {-value }\end{array}$} & 0.001 & 1.001 & 3346.200 & 0.054 & 6.940 & 0.271 \\
\hline & & \multirow{3}{*}{1044} & & \multirow{3}{*}{0.001} & \multirow{3}{*}{0.998} & 0.000 & 0.998 & 0.225 & 0.998 \\
\hline & \multirow{2}{*}{ SAN SM } & & & & & 7916.800 & 0.056 & 8.600 & 0.284 \\
\hline & & & & & & 0.000 & 0.998 & 0.126 & 0.998 \\
\hline \multirow{4}{*}{$\begin{array}{l}\text { REAL } \\
\text { ESTATE }\end{array}$} & \multirow{2}{*}{$\begin{array}{c}\text { ECMPA } \\
\text { NA }\end{array}$} & \multirow{4}{*}{$\begin{array}{l}1044 \\
1044\end{array}$} & \multirow{4}{*}{$\begin{array}{c}\text { Test } \\
p \text {-value } \\
\text { Test } \\
p \text {-value }\end{array}$} & \multirow[t]{2}{*}{0.007} & \multirow[t]{2}{*}{0.999} & 1369.300 & 0.460 & 3.101 & 2.185 \\
\hline & & & & & & 0.000 & 0.806 & 0.684 & 0.823 \\
\hline & \multirow{2}{*}{ ALV GR } & & & \multirow[t]{2}{*}{0.002} & \multirow[t]{2}{*}{0.999} & 861.600 & 0.482 & 3.124 & 2.508 \\
\hline & & & & & & 0.000 & 0.790 & 0.681 & 0.775 \\
\hline \multirow{4}{*}{$\begin{array}{c}\text { FINANC } \\
\text { SERV. }\end{array}$} & & 1044 & Test & 0.007 & 0.999 & $16,654.000$ & 0.076 & 7.025 & 0.391 \\
\hline & O4B GR & & $p$-value & & & 0.000 & 0.996 & 0.219 & 0.996 \\
\hline & & 1044 & Test & -0.007 & 0.999 & 521.110 & 0.197 & 0.869 & 1.045 \\
\hline & DBK GR & & $p$-value & & & 0.000 & 0.964 & 0.972 & 0.959 \\
\hline & GCO SM & 1044 & Test & -0.005 & 1.000 & 60.608 & 1.191 & 4.413 & 6.179 \\
\hline INSURANCE & Gcosin & & $p$-value & & & 0.000 & 0.311 & 0.492 & 0.289 \\
\hline IVSUNAIVEL & CS FP & 1044 & Test & -0.013 & 1.000 & & 0.273 & 9.252 & 1.365 \\
\hline & $\mathrm{CS} F$ & & $p$-value & & & & 0.928 & 0.099 & 0.928 \\
\hline & & Pane & Statistic & 1 Summa & $y$ for Vol & me Variation $I$ & Iodels & & \\
\hline & & 1044 & Test & -0.010 & 1.001 & 1748.400 & 0.229 & 0.887 & 1.145 \\
\hline BANKS & ACA FP & & $p$-value & & & 0.000 & 0.950 & 0.971 & 0.950 \\
\hline DANKS & SAN SM & 1044 & Test & -0.010 & 0.998 & 1064.300 & 0.459 & 3.439 & 2.364 \\
\hline & SAN SIVI & & $p$-value & & & 0.000 & 0.807 & 0.633 & 0.797 \\
\hline & ECMPA & 1044 & Test & 0.052 & 0.996 & 186.740 & 0.553 & 0.499 & 2.844 \\
\hline REAL & NA & & $p$-value & & & 0.000 & 0.736 & 0.992 & 0.724 \\
\hline ESTATE & ALV GR & 1044 & Test & -0.071 & 1.000 & 74,747.000 & 0.036 & 3.501 & 0.179 \\
\hline & ALV GK & & $p$-value & & & 0.000 & 0.999 & 0.623 & 0.999 \\
\hline & & 1044 & Test & 0.0067 & 1.0002 & 849.39 & 0.2356 & 12.101 & 1.079 \\
\hline FINANC & & & $p$-value & & & 0.000 & 0.947 & 0.0334 & 0.9559 \\
\hline SERV. & DBK GR & 1044 & Test & 0.006 & 1.000 & $472,210.000$ & 0.024 & 6.870 & 0.125 \\
\hline & DDK GK & & $p$-value & & & 0.000 & 1.000 & 0.230 & 1.000 \\
\hline & & 1044 & Test & 0.013 & 1.008 & 187.320 & 1.394 & 0.443 & 6.716 \\
\hline INSURANCE & GC & & $p$-value & & & 0.000 & 0.224 & 0.994 & 0.243 \\
\hline INSURANCE & CSFP & 1044 & Test & 0.001 & 1.000 & 2809.200 & 0.261 & 10.1842 & 1.31161 \\
\hline & $\mathrm{CSFP}$ & & $p$-value & & & 0.000 & 0.934 & 0.065 & 0.934 \\
\hline & Panel C. & istical & mmary fo & Bloomb & rg Invest & Sentiment I & lex Varia & ion Models & \\
\hline & & 1044 & Test & -0.006 & 0.999 & 289.360 & 0.514 & 0.172 & 2.611 \\
\hline & ACA FP & & $p$-value & & & 0.000 & 0.766 & 0.999 & 0.760 \\
\hline BANKS & & 1044 & Test & -0.003 & 0.999 & 34.887 & 0.819 & 6.759 & 4.187 \\
\hline & SAN SM & & $p$-value & & & 0.000 & 0.536 & 0.239 & 0.523 \\
\hline & ECMPA & 1044 & Test & -0.016 & 0.999 & $75,428.000$ & 0.109 & 6.432 & 0.552 \\
\hline REAL & NA & & $p$-value & & & 0.000 & 0.990 & 0.266 & 0.990 \\
\hline ESTATE & AIV GR & 1044 & Test & 0.002 & 0.999 & 28.541 & 0.936 & 2.737 & 4.646 \\
\hline & ALV GR & & $p$-value & & & 0.006 & 0.456 & 0.740 & 0.461 \\
\hline & & 1044 & Test & 0.060 & 0.889 & $76,348.000$ & 0.491 & 6.538 & 2.466 \\
\hline FINANC & O4B GR & & $p$-value & & & 0.000 & 0.783 & 0.257 & 0.782 \\
\hline SERV. & & 1044 & Test & -0.003 & 1.000 & 83.732 & 0.518 & 4.644 & 2.610 \\
\hline & DBK GR & & $p$-value & & & 0.000 & 0.763 & 0.461 & 0.760 \\
\hline & GCO SM & 1044 & Test & 0.000 & 1.000 & 324.86 & 0.0623 & 2.468 & 0.5386 \\
\hline INSURANCE & GCO SM & & $p$-value & & & 0.000 & 0.9971 & 0.7812 & 0.99063 \\
\hline & CS FP & 1044 & Test & 0.0271 & 0.9914 & 1,3019,000 & 0.0029 & 0.103206 & 0.01476 \\
\hline & & & $p$-value & & & 0.000 & 1.0000 & 0.9998 & 0.9999 \\
\hline
\end{tabular}

Note: Normality test is Jarque-Bera test, ARCH (lag = 5) is LM-test on heteroscedasticity, Box-Pierce (lag =5) is autocorrelation test on variable in level (mean equation) and in squared (variance equation). 
As we can see, the results of Table 3 indicate that the idiosyncratic shocks of the three variables (returns, volume and sentiment index) do not display autocorrelation and heteroscedasticity, so they are i.i.d.

\subsection{Comparison of Latent vs. Observable Factors Model}

We extract latent factors from covariance matrix of excess returns on assets. Table 4 show by subsectors: the total assets, the minimum number of factors necessary to explain at least $95 \%$ of the covariance matrix and the explanatory power of the first five factors (to compare results with the model of the five observable factors):

Table 4. Principal Components of covariance matrix.

\begin{tabular}{ccccc}
\hline Sub-Sector & Total Companies & Factors & \% Explanation & \% Explanation of First 5 PC \\
\hline Banks & 32 & 23 & $95.38 \%$ & $70.38 \%$ \\
Real Estate & 16 & 14 & $96.33 \%$ & $62.87 \%$ \\
Financial Institutions & 29 & 25 & $95.48 \%$ & $43.09 \%$ \\
Insurances & 8 & 7 & $96.85 \%$ & $87.87 \%$ \\
\hline
\end{tabular}

Table 5 shows the results of comparing the latent factors model against the observable factors model. Specifically, we contrast which of the two models has lower RMS alpha and lower volatility of the idiosyncratic risk.

Table 5. Results of the comparison of the latent and observable factor models.

\begin{tabular}{|c|c|c|c|c|c|c|}
\hline \multicolumn{7}{|c|}{ Observable Factors Model } \\
\hline \multirow{2}{*}{ Sub-Sector } & \multicolumn{3}{|c|}{ RMS Alpha } & \multicolumn{3}{|c|}{ Residual Deviation } \\
\hline & Min & Mean & Max & Min & Mean & Max \\
\hline Banks & $0.005 \%$ & $0.053 \%$ & $0.684 \%$ & $0.298 \%$ & $0.403 \%$ & $1.957 \%$ \\
\hline Real Estate & $0.001 \%$ & $0.014 \%$ & $0.058 \%$ & $0.140 \%$ & $0.194 \%$ & $0.738 \%$ \\
\hline Financial Institutions & $0.004 \%$ & $0.017 \%$ & $0.099 \%$ & $0.158 \%$ & $0.265 \%$ & $1.160 \%$ \\
\hline Insurances & $0.008 \%$ & $0.018 \%$ & $0.045 \%$ & $0.093 \%$ & $0.224 \%$ & $0.802 \%$ \\
\hline \multicolumn{7}{|c|}{ Latent Factors Model for 95\% Explanation } \\
\hline \multirow{2}{*}{ Sub-Sector } & \multicolumn{3}{|c|}{ RMS Alpha } & \multicolumn{3}{|c|}{ Residual Deviation } \\
\hline & Min & Mean & Max & Min & Mean & Max \\
\hline Banks & $0.026 \%$ & $0.109 \%$ & $0.744 \%$ & $0.044 \%$ & $0.512 \%$ & $1.762 \%$ \\
\hline Real Estate & $0.002 \%$ & $0.037 \%$ & $0.094 \%$ & $0.006 \%$ & $0.157 \%$ & $0.602 \%$ \\
\hline Financial Institutions & $0.007 \%$ & $0.048 \%$ & $0.168 \%$ & $0.022 \%$ & $0.244 \%$ & $1.004 \%$ \\
\hline Insurances & $0.0124 \%$ & $0.025 \%$ & $0.072 \%$ & $0.007 \%$ & $0.191 \%$ & $0.766 \%$ \\
\hline \multicolumn{7}{|c|}{ Latent Factors Model for First 5 PC } \\
\hline \multirow{2}{*}{ Sub-Sector } & \multicolumn{3}{|c|}{ RMS Alpha } & \multicolumn{3}{|c|}{ Residual Deviation } \\
\hline & Min & Mean & Max & Min & Mean & Max \\
\hline Banks & $0.026 \%$ & $0.109 \%$ & $0.744 \%$ & $0.737 \%$ & $1.081 \%$ & $2.243 \%$ \\
\hline Real Estate & $0.002 \%$ & $0.037 \%$ & $0.094 \%$ & $0.288 \%$ & $0.352 \%$ & $1.094 \%$ \\
\hline Financial Institutions & $0.007 \%$ & $0.048 \%$ & $0.168 \%$ & $0.248 \%$ & $0.329 \%$ & $1.865 \%$ \\
\hline Insurances & $0.0124 \%$ & $0.025 \%$ & $0.072 \%$ & $0.185 \%$ & $0.470 \%$ & $0.894 \%$ \\
\hline
\end{tabular}

Note that the standard deviation of the residuals (idiosyncratic component of the model) shows the lowest values for the latent factors model. However, when we compare the model of 5 latent factors with the model of 5 observable factors, we find that the latter shows a lower volatility of the idiosyncratic component. On the other hand, if we compare the intercept (alpha), we find empirical evidence that the latent models present higher anomalies than the observable factors model (as [89] hidden factor models performance more poorly). This is due to the fact that while the latent factor models explain the covariances, the same does not occur with the mean, so that the constant shows higher values.

In addition to this evidence found, if we consider that the data are in daily frequency with the consequent problem of behavior of the residuals (autoregressiveness, heteroskedas- 
ticity and heavy tails) then, we choose the estimation of the observable factors model and adjusting a GARCH process to the variance of the residuals, since CPA is more consistent when the data show Gaussian behavior (for example, asset returns in monthly frequency).

\subsection{Comparison of the Influence of Investor Sentiment Index Shocks}

First, using information criteria (AIC), it was determined that delay 3 was sufficient to adjust the model and then individual linear regressions were estimated. The results are shown in Table 6.

Table 6. Individual estimate of the influence of the investor sentiment index.

\begin{tabular}{|c|c|c|c|c|c|c|}
\hline \multirow{2}{*}{$\begin{array}{c}\text { Subsectors } \\
\text { Banks }\end{array}$} & \multicolumn{3}{|c|}{ Abnormal Returns } & \multicolumn{3}{|c|}{ Volume Shocks } \\
\hline & Lag-1 & Lag-2 & Lag-3 & Lag-1 & Lag-2 & Lag-3 \\
\hline Portuguese commercial bank & & & $0.0611\left(^{*}\right)$ & & & \\
\hline Caixa Bank & & & $-0.0593(*)$ & & & $0.0167(*)$ \\
\hline National Bank of Greece & & & $-0.0632(*)$ & & & 0.0107 (1) \\
\hline KBC Group & & & & & $0.0054\left(^{* *}\right)$ & \\
\hline Raiffeisen Bank & & & & & $0.0125 * * *$ & \\
\hline Banco Santander & & & & & & $0.0055(*)$ \\
\hline TCS Group Holding & & & & & $0.0148\left(^{*}\right)$ & \\
\hline Unicredit & & & $0.0974(* *)$ & & & \\
\hline Real estate & Lag-1 & Lag-2 & Lag-3 & Lag-1 & Lag-2 & Lag-3 \\
\hline Ageas Group & & & & $-0.0595\left(^{*}\right)$ & & \\
\hline Citycon & & & & $\left.-0.0639{ }^{*}\right)$ & & \\
\hline Hanover Rueck & & $-0.0853(* *)$ & & & & $-0.0683\left(^{*}\right)$ \\
\hline Nexity & & & & $0.0737\left(^{*}\right)$ & & \\
\hline Talanx & & & & $0.0912(* *)$ & & $\left.-0.0761{ }^{*}\right)$ \\
\hline Technopolis & & & & & & $-0.0656\left(^{*}\right)$ \\
\hline Finance & Lag-1 & Lag-2 & Lag-3 & Lag-1 & Lag-2 & Lag-3 \\
\hline ABC Arbitrage & $0.0869(* *)$ & & & & & \\
\hline Azimut Holding & & $0.0687\left(^{*}\right)$ & & & & \\
\hline CIE du Bois Sauvage & & $\left.-0.0605{ }^{*}\right)$ & & & & \\
\hline Deutsche Beteiligungs & & & & & $0.0617\left(^{*}\right)$ & \\
\hline Deutsche Bank AG & $0.0689\left(^{*}\right)$ & & & & & \\
\hline KAS Bank NV-CVA & & & & & & $-0.0726\left(^{*}\right)$ \\
\hline Natixis & $-0.0594\left(^{*}\right)$ & & & & & \\
\hline Altamir & & & & $\left.-0.0639{ }^{*}\right)$ & & \\
\hline MLP & $0.0685\left(^{*}\right)$ & & & & & \\
\hline Rothschild & $-0.0823(* *)$ & & & & & \\
\hline Insurance & Lag-1 & Lag-2 & Lag-3 & Lag-1 & Lag-2 & Lag-3 \\
\hline $\begin{array}{l}\text { CNPFP Assurances } \\
\text { MAPFRE }\end{array}$ & & $0.0618\left(^{*}\right)$ & $-0.0610\left(^{*}\right)$ & & $0.0708\left(^{*}\right)$ & \\
\hline
\end{tabular}

Note: $\left.{ }^{*}\right)$ and $(* *)$ indicate that the parameter is significant at the confidence level of $5 \%$ and $1 \%$ respectively.

As can be seen in Table 4, of the 85 companies in the sample, only 26 show any effect either on returns or volume or both. Thus, $31 \%$ of the sample shows effects and, by subsector, it would be: $25 \%$ banks (mostly from countries where the financial crisis had a greater impact on the sector such as Spain, Portugal, Italy, Greece and Cyprus), 38\% real estate, $34 \%$ finance and $25 \%$ insurance companies.

Next, to check the possible effect of contagion between companies in the same activity subgroup, we estimated a system of equations using FIML (Full Information Maximum Likelihood). The goal is to check whether, when making a joint estimate, companies that individually did not show statistical significance (see Table 6), do so jointly. In that case, the results would indicate that the sentiment index of these companies would be influenced not only by news about them but also by other companies in the subsector. Table 7 shows the results obtained. 
Table 7. Subsectors estimate of the influence of the investor sentiment index.

\begin{tabular}{|c|c|c|c|c|c|c|c|c|}
\hline \multirow{2}{*}{$\begin{array}{c}\text { Subsectors } \\
\text { Banks }\end{array}$} & \multicolumn{4}{|c|}{ Abnormal Returns } & \multicolumn{4}{|c|}{ Volume Shocks } \\
\hline & Individ. effect & Lag-1 & Lag-2 & Lag-3 & Individ. effect & Lag-1 & Lag-2 & Lag-3 \\
\hline Allied Irish Banks & No & & & & No & $0.0609\left(^{*}\right)$ & & \\
\hline Aareal Bank & No & & $-0.0498\left(^{*}\right)$ & & & & & \\
\hline Banco BPM & & $0.0428\left(^{*}\right)$ & & & & & & \\
\hline BBVA & & $-0.0368\left(^{*}\right)$ & & & & & & \\
\hline Portuguese commercial bank & Yes & $-0.0483(*)$ & & $\left.0.07388^{* *}\right)$ & No & & $0.0668\left(^{*}\right)$ & \\
\hline Bankia & & & & $-0.0522\left(^{*}\right)$ & No & & & $-0.0494\left(^{*}\right)$ \\
\hline Caixa Bank & Yes & & & $-0.0682\left(^{*}\right)$ & Yes & & & $0.0141\left(^{*}\right)$ \\
\hline BPER Banca & No & $-0.0508\left(^{*}\right)$ & & & & & & \\
\hline ING Groep & No & $-0.0471\left(^{*}\right)$ & & & No & $-0.0471\left(^{*}\right)$ & & \\
\hline Banco de Sabadell & No & $-0.0554\left(^{*}\right)$ & & & & & & \\
\hline Piraeus Bank & No & & $-0.0389\left(^{*}\right)$ & & & & & \\
\hline Intesa Sanpaolo & & & & & No & $-0.0792(* *)$ & & \\
\hline Raiffeisen Bank & & & & & Yes & $0.0679\left(^{*}\right)$ & & \\
\hline Banco Santander & & & & & Yes & & $0.0631\left(^{*}\right)$ & \\
\hline TCS Group Holding & & & & & Yes & $0.0568\left(^{*}\right)$ & & \\
\hline Unicredit & Yes & & & $0.0926\left(^{* *}\right)$ & Yes & $0.0568\left(^{*}\right)$ & & \\
\hline Ageas Group & No & & & $0.0526\left({ }^{*}\right)$ & Yes & $-0.0563\left(^{*}\right)$ & & \\
\hline Citycon & & & & & Yes & $-0.0530\left(^{*}\right)$ & & \\
\hline Hanover Rueck & Yes & $-0.0679\left(^{(* *)}\right.$ & & & Yes & & & $-0.0485\left(^{*}\right)$ \\
\hline Muenchener Rueckver & No & & & $-0.0773^{(* *)}$ & No & $0.0192\left(^{*}\right)$ & & \\
\hline Nuerberger Beteilig & No & $-0.1038^{(* *)}$ & & & & & & \\
\hline Vienna Insurance Group & No & & & $-0.0591\left(^{*}\right)$ & No & & $-0.0507\left(^{*}\right)$ & \\
\hline Nexity & & & & & Yes & $0.0822(* *)$ & & \\
\hline Talanx & & & & & Yes & $0.0815\left(^{* *}\right)$ & & $-0.0652\left(^{*}\right)$ \\
\hline Technopolis & & & & & Yes & & & $-0.0724\left(^{*}\right)$ \\
\hline
\end{tabular}


Table 7. Cont

\begin{tabular}{|c|c|c|c|c|c|c|c|c|}
\hline \multirow{2}{*}{$\begin{array}{c}\text { Subsectors } \\
\text { Finance }\end{array}$} & \multicolumn{4}{|c|}{ Abnormal Returns } & \multicolumn{4}{|c|}{ Volume Shocks } \\
\hline & Individual effect & Lag-1 & Lag-2 & Lag-3 & $\begin{array}{c}\text { Individual } \\
\text { effect }\end{array}$ & Lag-1 & Lag-2 & Lag-3 \\
\hline ABC Arbitrage & Yes & $0.0756\left(^{*}\right)$ & & & & & & \\
\hline Azimut Holding & Yes & & $0.0542\left(^{*}\right)$ & & & & & \\
\hline Banca Generali & No & & & $0.0537\left(^{*}\right)$ & & & & \\
\hline CIE du Bois Sauvage & Yes & & $-0.0674\left(^{*}\right)$ & & & & & \\
\hline Deutsche Banck AG & Yes & $0.0637\left(^{*}\right)$ & & & & & & \\
\hline Groupe Bruxelles Lambert & No & $0.0456\left(^{*}\right)$ & & & & & & \\
\hline Banca IFIS & No & & & $0.0509\left(^{*}\right)$ & & $-0.0604\left(^{*}\right)$ & & \\
\hline KAS Bank NV-CVA & No & $-0.0619\left(^{*}\right)$ & & & Yes & & & $-0.0642\left(^{*}\right)$ \\
\hline Natixis & Yes & $-0.0540\left(^{*}\right)$ & & & & & & \\
\hline MLP & Yes & $0.0563\left(^{*}\right)$ & & & & & & \\
\hline Rothschild & Yes & $-0.0764\left(^{*}\right)$ & & & & & & \\
\hline Deustsche Beteiligungs & & & & & Yes & & $0.0655\left(^{*}\right)$ & \\
\hline FP & & & & & No & & & $0.0557\left(^{*}\right)$ \\
\hline KBC Ancora & & & & & No & & & $\left.0.0619{ }^{*}\right)$ \\
\hline Altamir & & & & & Yes & $-0.0717\left(^{*}\right)$ & & \\
\hline Sofina & & & & & No & & & $0.0551\left(^{*}\right)$ \\
\hline Insurance & Individual effect & Lag-1 & Lag-2 & Lag-3 & $\begin{array}{c}\text { Individual } \\
\text { effect }\end{array}$ & Lag-1 & Lag-2 & Lag-3 \\
\hline Cattolica Assicurazioni & No & $0.0562\left(^{*}\right)$ & & & & & & \\
\hline MAPFRE & Yes & & $0.0491\left(^{*}\right)$ & & & & & \\
\hline CNPFP Assurances & Yes & & & $-0.0574\left(^{*}\right)$ & Yes & & $0.0628\left(^{*}\right)$ & \\
\hline
\end{tabular}

Note: $\left({ }^{*}\right)$ and $(* *)$ indicate that the parameter is significant at the confidence level of $5 \%$ and $1 \%$ respectively. 
As can be seen in Table 7, the number of companies with significant effects from investor sentiment index shock has increased, that is, other companies have now been added to all those that were individually significant. It seems clear that there is an effect by subsector.

We then estimated the panel data model with asymmetric effect by subsector. First the Hausman test was estimated, whose values were 17.07 ( $p$-value of 0.846) for abnormal returns and 11.36 ( $p$-value of 0.986 ) for idiosyncratic volume shocks. As a result, the assumption of random effects is accepted in both cases. The within-between GLS estimate is chosen. Table 6 (Panel A and B) shows the results of the estimate of the panel data models corresponding to Expression (12), both for abnormal returns and for volume shocks. The explanatory power, measured by the coefficient of determination was $0.45 \%$ and $0.51 \%$, respectively, which would indicate the limited influence of the shocks of the Bloomberg sentiment index on the idiosyncratic shocks of returns and volume.

The results in Table 8 show that there is only an effect on abnormal returns when the previous days' returns were negative and, while for banks and real estate companies the effect comes from the shock of the previous day's sentiment index, for financial services and insurance companies the delay is slightly longer (three and two days, respectively).

Table 8. Estimate of the asymmetric and subsector influence of the investor sentiment index.

\begin{tabular}{|c|c|c|c|c|c|c|}
\hline \multirow{2}{*}{ Parameters } & \multicolumn{3}{|c|}{ Panel A. Abnormal Returns } & \multicolumn{3}{|c|}{ Panel B. Volume Shocks } \\
\hline & Coefficient & Typ. Dev. & $p$ Value & Coefficient & Typ. Dev. & $p$ Value \\
\hline Constant & -0.0090 & 0.0043 & 0.0354 * & 0.0037 & 0.0042 & 0.3755 \\
\hline news_bank_t-1 (+) & 0.0028 & 0.0074 & 0.7034 & 0.0148 & 0.0072 & 0.0389 * \\
\hline news_bank_t-2 (+) & -0.0058 & 0.0084 & 0.4925 & 0.0034 & 0.0080 & 0.6674 \\
\hline news_bank_t-3 (+) & 0.0060 & 0.0098 & 0.5401 & 0.0162 & 0.0078 & 0.0377 * \\
\hline news_bank_t-1 (-) & -0.0152 & 0.0076 & 0.0469 * & 0.0026 & 0.0073 & 0.7242 \\
\hline news_bank_t-2 (-) & 0.0037 & 0.0088 & 0.6728 & 0.0010 & 0.0076 & 0.8920 \\
\hline news_bank_t-3 (-) & 0.0001 & 0.0089 & 0.9900 & -0.0059 & 0.0077 & 0.4435 \\
\hline news_real estate_t-1 (+) & -0.0050 & 0.0163 & 0.7612 & 0.0055 & 0.0111 & 0.6168 \\
\hline news_real estate_t-2 (+) & 0.0080 & 0.0106 & 0.4498 & -0.0096 & 0.0122 & 0.4321 \\
\hline news_real estate_t-3 (+) & 0.0111 & 0.0116 & 0.3383 & -0.0117 & 0.0147 & 0.4268 \\
\hline news_real estate_t-1 (-) & -0.0170 & 0.0080 & 0.0353 * & 0.0140 & 0.0114 & 0.2197 \\
\hline news_real estate_t-2 (-) & 0.0077 & 0.0114 & 0.4992 & -0.0201 & 0.0102 & 0.0484 * \\
\hline news_real estate_t-3 (-) & -0.0052 & 0.0115 & 0.6535 & -0.0171 & 0.0187 & 0.3591 \\
\hline news_finance_t $-1(+)$ & 0.0080 & 0.0094 & 0.3939 & 0.0013 & 0.0079 & 0.8723 \\
\hline news_finance_t $-2(+)$ & -0.0011 & 0.0082 & 0.8965 & 0.0064 & 0.0078 & 0.4148 \\
\hline news_finance_t-3 $(+)$ & 0.0144 & 0.0079 & 0.0701 & -0.0020 & 0.0080 & 0.8047 \\
\hline news_finance_t-1 (-) & 0.0032 & 0.0087 & 0.7144 & -0.0256 & 0.0085 & $0.0028 * *$ \\
\hline news_finance_t-2 (-) & -0.0026 & 0.0076 & 0.7305 & 0.0006 & 0.0074 & 0.9348 \\
\hline news_finance_t $-3(-)$ & 0.0134 & 0.0057 & 0.0185 * & 0.0037 & 0.0083 & 0.6570 \\
\hline news_insurance_t-1 (+) & -0.0080 & 0.0149 & 0.5930 & -0.0210 & 0.0166 & 0.2045 \\
\hline news_insurance_t-2 (+) & -0.0036 & 0.0157 & 0.8211 & 0.0072 & 0.0174 & 0.6807 \\
\hline news_insurance_t $-3(+)$ & -0.0104 & 0.0160 & 0.5150 & 0.0063 & 0.0173 & 0.7165 \\
\hline news_insurance_t-1 (-) & -0.0006 & 0.0163 & 0.9703 & 0.0051 & 0.0126 & 0.6869 \\
\hline news_insurance_t-2 $(-)$ & 0.0255 & 0.0130 & 0.0491 * & 0.0187 & 0.0152 & 0.2184 \\
\hline news_insurance_t-3 (-) & -0.0151 & 0.0178 & 0.3974 & -0.0050 & 0.0159 & 0.7519 \\
\hline
\end{tabular}

Note: ${ }^{*}$ and ${ }^{* *}$ indicate that the parameter is significant at the confidence level of $5 \%$ and $1 \%$ respectively.

The effects in terms of volume are more disparate. The effect is the greatest (one and three previous days) in banking and only when the volume variation of the previous days was positive. For insurance companies the significant effect is the day before but only when the volume change on that date was negative. For real estate companies the effect has a longer delay (two days) and also when there is a drop in volume. 


\section{Discussion}

In recent years and in the empirical financial literature, research has been carried out to verify whether investor sentiment has any capacity to explain the behavior of financial assets. To analyzed this individual causal relationship, we carried out two prior tasks.

First and unlike some of the literature $[12,17,37,88]$, we adjusted an asset pricing model to extract so-called abnormal returns (idiosyncratic risk), because otherwise we would not be analyzing the effect of investor sentiment on a given asset but rather including systematic risk.

Second, to avoid diluting the effect of shock on low frequency data $[18,22,32,66]$ and the subjectivity of the surveys (see [40]) an investor sentiment index had to be applied. As a result, the literature on fashioning sentiment indexes has proliferated, even inciting financial information providers, such as Bloomberg and Reuters, to build and publish their own.

In this context, this paper aims to analyzed the influence, measured as causality, of Bloomberg investor sentiment indexes for the EU financial sector. The selection of the sample is based on the results of previous research into the geographical, socio-economic and activity factors. The sample is composed of $85 \mathrm{EU}$ financial institutions representing more than $95 \%$ of the sector in capitalization (market value) and size (asset value).

The empirical results draw three main conclusions. First, the influence of the investor sentiment index shocks produced by Bloomberg is very low ( $R^{2}$ around $\left.0.5 \%\right)$. Second, the effect of investor sentiment index shocks is asymmetric, that is, the effect is different if return (volume) had risen or fallen in the previous days.

Thirdly, the effect is due more to a sectoral or activity aspect (banking, real estate, finance or insurance) than to individual characteristic of each firm.

These results provide a more accurate view of the influence of investor sentiment and a greater understanding of stock performance in reaction to this sentiment, as [86] states that different trading strategies based on this index outperform the benchmark ETF index and [80] find a relationship between stock prices and their sentiment index when the company's coverage in social networks is extensive. In summary, as a consequence of the evidence found, Bloomberg investor sentiment index has a slight influence (causality) on idiosyncratic shocks, possibly due to the construction of the index itself, which includes the news published in an aggregated way instead of considering them individually, as in [38]. By contrast, at the level of activity or subsector, it would be advisable that sentiment indexes be calculated at the sectorial rather than individual level.

Regarding the limitations of empirical studies on sentiment indexes of investors, the main drawback is the opacity in the construction of the indexes. This lack of transparency makes it difficult to contrast the relevance of index. So future researches should include a transparency section on the construction of these indices. Further, according to the conclusions obtained in this study, the calculation of indexes focused on sectors, instead of individual companies, would contain information more useful for inexperienced investors.

Author Contributions: M.G.-S. and M.E.M.d.V.; methodology, M.G.-S. and M.E.M.d.V.; software, M.G.-S. and M.E.M.d.V.; validation, M.G.-S. and M.E.M.d.V.; formal analysis, M.G.-S. and M.E.M.d.V.; investigation, M.G.-S. and M.E.M.d.V.; resources, M.G.-S. and M.E.M.d.V.; data curation, M.G.S. and M.E.M.d.V.; writing—original draft preparation, M.G.-S. and M.E.M.d.V.; writing—review and editing, M.G.-S. and M.E.M.d.V.; visualization, M.G.-S. and M.E.M.d.V.; supervision, M.G.-S. and M.E.M.d.V.; project administration, M.G.-S. and M.E.M.d.V.; funding acquisition, M.G.-S. and M.E.M.d.V. All authors have read and agreed to the published version of the manuscript.

Funding: This work has been supported by the Spanish Ministry of Economics and Competitiveness under grant MINECO/FEDER ECO2015-65826-P and C'atedra Universidad CEU San Pablo-Mutua Madrileña insurance company (grant ARMEG 060516-USPMM-01/17).

Conflicts of Interest: The authors declare no conflict of interest. 


\section{Appendix A}

The sample consists of the following financial institutions with ticker and country into parenthesis:

- Banking: BANCO SANTANDER (SAN SM, Spain), TCS GROUP HOLDING UCG IM -REG S (TCS LI, Cyprus), PIRAEUS BANK S.A (TPEIR GA, Greece), UBI BANCA SPA (UBI IM, Italy), UNICREDIT SPA (UCG IM, Italy), ALLIED IRISH BANKS PLC (ALBK ID, Ireland), BANKINTER SA (BKT SM, Spain), CAIXABANK S.A (CABK SM, Spain), BNP PARIBAS (BNP FP, France), CREDIT AGRICOLE SA (ACA FP, France), ALPHA BANK AE (ALPHA GA, Greece), AAREAL BANK AG (ARL GR, Germany), BANCO BPM SPA (BAMI IM, Italy), BANCO BILBAO VIZCAYA ARGENTA (BBVA SM, Spain), MEDIOBANCA SPA (MB IM, Italy), RAIFFEISEN BANK INTER- NATIONA (RBI AV, Austria), BANCO DE SABADELL SA (SAB SM, Spain), BANCO COMER- CIAL PORTUGUES-R (BCP PL, Portugal), BANK OF IRELAND GROUP PLC (BIRG ID, Ireland), BANKIA SA (BKIA SM, Spain), BANCA MONTE DEI PASCHI SIENA (BMPS IM, Italy), BPER BANCA (BPE IM, Italy), BANCA POPOLARE DI SONDRIO (BPSO IM, Italy), COMMERZBANK AG (CBK GR, Germany), CREDITO EMILIANO SPA (CE IM, Italy), ERSTE GROUP BANK AG (EBS AV, Germany), NATIONAL BANK OF GREECE (ETE GA, Greece), EUROBANK ERGASIAS SA (EUROB GA, Greece), SOCIETE GENERALE SA (GLE FP, France), ING GROEP NV (INGA NA, Netherlands), INTESA SANPAOLO (ISP IM, Italy), KBC GROUP NV (KBC BB, Belgium).

- Real estate: SPONDA OYJ (SDA1 FH, Finland), AGEAS (AGS BB, Belgium), ALLIANZ SE-REG (ALV GR, Germany), CITYCON OYJ (CTY1S FH, Finland), EUROCOMMERCIAL PROPERTIE- CV (ECMPA NA, Netherlands), GRAND CITY PROPERTIES (GYC GR, Germany), HANNOVER RUECK SE (HNR1 GR, Germany), MUENCHENER RUECKVER AG-REG (MUV2 GR, Germany), NUERNBERGER BETEILIG-AKT 'B' (NBG6 GR, Germany), NEXITY (NXI FP, France), RE- ALIA BUSINESS SA (RLIA SM, Spain), TALANX AG (TLX GR, Germany), TECHNOPOLIS OYJ (TPS1V FH, Finland), UNIQA INSURANCE GROUP AG (UQA AV, Austria), VIENNA INSUR- ANCE GROUP AG (VIG AV, Austria), WUESTENROT \& WUERTTEMBERG (WUW GR, Germany).

- $\quad$ Financial services: NATIXIS (KN FP, France), ALTAMIR (LTA FP, France), LUXEMPART SA (LXMP LX, Luxembourg), MLP SE (MLP GR, Germany), MUTARES AG (MUX GR, Germany), REINET INVESTMENTS SCA (REIN LX, Luxembourg), EURAZEO SA (RF FP, France), ROTH- SCHILD \& CO (ROTH FP, France), SOFINA (SOF BB, Belgium), BANK OF GREECE (TELL GA, Greece), GRENKE AG (GLJ GR, Germany), DEUTSCHE BALATON AG (BBH GR, Ger- many), REINET INVESTMENTS SCA (O4B GR, Germany), VARENGOLD BANK AG (VG8 GR, Germany), ABC ARBITRAGE (ABCA FP, France), ACKERMANS \& VAN HAAREN (ACKB BB, Belgium), AZIMUT HOLDING SPA (AZM IM, Italy), BANCA GENERALI SPA (BGN IM, Italy), BINCKBANK NV (BINCK NA, Netherlands), BANQUE NATIONALE DE BELGIQUE (BNB BB, Belgium), CIE DU BOIS SAUVAGE SA (COMB BB, Belgium), DEUTSCHE BETEILIGUNGS AG (DBAN GR, Germany), DEUTSCHE BANK AG-REGISTERED (DBK GR, Germany), FFP (FFP FP, France), GROUPE BRUXELLES LAMBERT SA (GBLB BB, Belgium), GIMV NV (GIMB BB, Belgium), BANCA IFIS SPA (IF IM, Italy), KAS BANK NV-CVA (KA NA, Netherlands), KBC ANCORA (KBCA BB, Belgium).

- Insurance: SCOR SE (SCR FP, France), CATTOLICA ASSICURAZIONI SC (CASS IM, Italy), MAPFRE SA (MAP SM, Spain), GRUPO CATALANA OCCIDENTE SA (GCO SM, Spain), AEGON NV (AGN NA, Netherlands), CNP ASSURANCES (CNP FP, France), AXA SA (CS FP, France), SAMPO OYJ-A SHS (SAMPO FH, Finland). 


\section{References}

1. Smales, L.A. The importance of fear: Investor sentiment and stock market returns. Appl. Econ. 2017, 49, 3395-3421. [CrossRef]

2. Bowman, R.G. Understanding and conducting event studies. J. Bus. Financ. Account. 1983, 10, 561-584. [CrossRef]

3. De Long, J.B.; Shleifer, A.; Summers, L.H.; Waldmann, R.J. Noise trader risk in financial markets. J. Political Econ. 1990, 98, 703-738. [CrossRef]

4. Lee, C.M.; Shleifer, A.; Thaler, R.H. Investor sentiment and the closed-end fund puzzle. J. Financ. 1991, 46, 75-109. [CrossRef]

5. Pritamani, M.; Singal, V. Return predictability following large price changes and information releases. J. Bank. Financ. 2001, 25, 631-656. [CrossRef]

6. Brown, G.W.; Cliff, M.T. Investor sentiment and the near-term stock market. J. Empir. Financ. 2004, 11, 1-27. [CrossRef]

7. Kumar, A.; Lee, C.M. Retail investor sentiment and return co-movements. J. Financ. 2006, 61, 2451-2486. [CrossRef]

8. Baker, M.; Wurgler, J.; Yuan, Y. Investor sentiment in the stock market. J. Econ. Perspect. 2007, 21, 129-152. [CrossRef]

9. Tetlock, P.C. Giving content to investor sentiment: The role of media in the stock market. J. Financ. 2007, 62, 1139-1168. [CrossRef]

10. Chung, S.L.; Hung, C.H.; Yeh, C.Y. When does investor sentiment predict stock returns? J. Empir. Financ. 2012, 19, 217-240. [CrossRef]

11. Corredor, P.; Ferrer, E.; Santamaria, R. Investor sentiment effect in stock markets: Stock characteristics or country-specific factors? Int. Rev. Econ. Financ. 2013, 27, 572-591. [CrossRef]

12. Yuan, Y. Market-wide attention, trading, and stock returns. J. Financ. Econ. 2015, 116, 548-564. [CrossRef]

13. Loughran, T.; McDonald, B. Textual analysis in accounting and finance: A survey. J. Account. Res. 2016, 54, 1187-1230. [CrossRef]

14. Nardo, M.; Petracco-Giudici, M.; Naltsidis, M. Walking down Wall Street with a tablet: A survey of stock market predictions using the web. J. Econ. Surv. 2016, 30, 356-369. [CrossRef]

15. Heidinger, D.; Gatzert, N. Awareness, determinants and value of reputation risk management: Empirical evidence from the banking and insurance industry. J. Bank. Financ. 2018, 91, 106-118. [CrossRef]

16. García, D. Sentiment during recessions. J. Financ. 2013, 68, 1267-1300. [CrossRef]

17. Smales, L.A. Asymmetric volatility response to news sentiment in gold futures. J. Int. Financ. Mark. Inst. Money 2014, 34, 161-172. [CrossRef]

18. He, Z. Dynamic impacts of crude oil price on Chinese investor sentiment: Nonlinear causality and time-varying effect. Int. Rev. Econ. Financ. 2020, 66, 131-153. [CrossRef]

19. Verma, R.; Verma, P. Noise trading and stock market volatility. J. Multinatl. Financ. Manag. 2007, 17, 231-243. [CrossRef]

20. Renault, T. Intraday online investor sentiment and return patterns in the US stock market. J. Bank. Financ. 2017, 84, 25-40. [CrossRef]

21. Johnman, M.; Vanstone, B.J.; Gepp, A. Predicting FTSE 100 returns and volatility using sentiment analysis. Account. Financ. 2018, 58, 253-274. [CrossRef]

22. Xiong, X.; Meng, Y.; Li, X.; Shen, D. Can overnight return really serve as a proxy for firm-specific investor sentiment? Cross-country evidence. J. Int. Financ. Mark. Inst. Money 2020, 64, 1-14. [CrossRef]

23. Chan, R.; Durand, F.; Khuu, J.; Smales, L.A. The validity of investor sentiment proxies. Int. Rev. Financ. 2017, 17, 473-477. [CrossRef]

24. Fama, E.F. Efficient Capital Market II. J. Financ. 1991, 46, 573-617. [CrossRef]

25. Fama, E.F.; French, K.R. The cross-section of expected stock returns. J. Financ. 1992, 47, 427-465. [CrossRef]

26. Fama, E.F.; French, K.R. Common risk factors in the returns on stocks and bonds. J. Financ. Econ. 1993, 33, 3-56. [CrossRef]

27. Fama, E.F.; French, K.R. Multifactor explanations of asset pricing anomalies. J. Financ. 1996, 51, 55-84. [CrossRef]

28. Schmeling, M. Investor sentiment and stock returns: Some international evidence. J. Empir. Financ. 2009, 16, 394-408. [CrossRef]

29. Guti'errez, J.A.; Martínez, V.; Tse, Y. Where does return and volatility come from? The case of Asian ETFs. Int. Rev. Econ. Financ. 2009, 18, 671-679. [CrossRef]

30. Zouaoui, M.; Nouyrigat, G.; Beer, F. How does investor sentiment affect stock market crises? Evidence from panel data. Financ. Rev. 2011, 46, 723-747. [CrossRef]

31. Chiou, W.J.P.; Lee, A.C.; Lee, C.F. Stock return, risk, and legal environment around the world. Int. Rev. Econ. Financ. 2010, 19, 95-105. [CrossRef]

32. Uhl, M.W. Reuters sentiment and stock returns. J. Behav. Financ. 2014, 15, 287-298. [CrossRef]

33. Guo, K.; Sun, Y.; Qian, X. Can investor sentiment be used to predict the stock price? Dynamic analysis based on china stock market. Phys. A Stat. Mech. Appl. 2017, 469, 390-396. [CrossRef]

34. Smales, L.A. News sentiment and bank credit risk. J. Empir. Financ. 2016, 38, 37-61. [CrossRef]

35. Gómez-Carrasco, P.; Michelon, G. The power of stakeholders' voice: The effects of social media activism on stock markets. Bus. Strategy Environ. 2017, 26, 855-872. [CrossRef]

36. Barakat, A.; Ashby, S.; Fenn, P.; Bryce, C. On the time scale behavior of equity-commodity links: Implications for portfolio management. J. Bank. Financ. 2019, 98, 1-24. [CrossRef]

37. Piñeiro, J.R.; López, M.A.; Pérez, A.M. Examining the influence of stock market variables on microblogging sentiment. J. Bus. Res. 2016, 69, 2087-2092. [CrossRef]

38. González-Sánchez, M.; Morales de Vega, M.E. Corporate reputation and firms' performance: Evidence from Spain. Corp. Soc. Responsib. Environ. Manag. 2018, 25, 1231-1245. [CrossRef]

39. Antweiler, W.; Frank, M.Z. Is all that talk just noise? The information content of internet stock message boards. J. Financ. 2004, 59, 1259-1294. [CrossRef] 
40. Sun, L.; Najand, M.; Shen, J. Stock return predictability and investor sentiment: A high-frequency perspective. J. Bank. Financ. 2016, 73, 147-164. [CrossRef]

41. Baker, M.; Wurgler, J. Investor sentiment and the cross-section of stock returns. J. Financ. 2006, 61, 1645-1680. [CrossRef]

42. Da, Z.; Engelberg, J.; Gao, P. The sum of all FEARS investor sentiment and asset prices. Rev. Financ. Stud. 2014, 28, 1-32. [CrossRef]

43. Fisher, K.L.; Statman, M. Consumer confidence and stock returns. J. Portf. Manag. 2003, 30, 115-127. [CrossRef]

44. Lemmon, M.; Portniaguina, E. Consumer confidence and asset prices: Some empirical evidence. Rev. Financ. Stud. 2006, 19, 1499-1529. [CrossRef]

45. Schmeling, M. Institutional and individual sentiment: Smart money and noise trader risk? Int. J. Forecast. 2007, 23, 127-145. [CrossRef]

46. Ho, C.; Hung, C.H. Investor sentiment as conditioning information in asset pricing. J. Bank. Financ. 2009, 33, 892-903. [CrossRef]

47. Stambaugh, R.F.; Yu, J.; Yuan, Y. The short of it: Investor sentiment and anomalies. Eur. Financ. Manag. 2012, 104, 288-302. [CrossRef]

48. Fisher, K.L.; Statman, M. Investor sentiment and stock returns. Financ. Anal. J. 2000, 56, 16-23. [CrossRef]

49. Kurov, A. Investor sentiment, trading behavior and informational efficiency in index futures markets. Financ. Rev. 2008, 43, 107-127. [CrossRef]

50. Verma, R.; Soydemir, G. The impact of individual and institutional investor sentiment on the market price of risk. Q. Rev. Econ. Financ. 2009, 49, 1129-1145. [CrossRef]

51. Fong, W.M. Risk preferences, investor sentiment and lottery stocks: A stochastic dominance approach. J. Behav. Financ. 2013, 14, 42-52. [CrossRef]

52. Johnk, D.; Soydemir, G. Time-varying market price of risk and investor sentiment: Evidence from a multivariate GARCH model. J. Behav. Financ. 2015, 16, 105-119. [CrossRef]

53. Frijns, B.; Huynh, T.D. Herding in analysts recommendations: The role of media. J. Bank. Financ. 2018, 91, 1-18. [CrossRef]

54. Jansen, W.J.; Nahuis, N.J. The stock market and consumer confidence: European evidence. Econ. Lett. 2003, 79, 89-98. [CrossRef]

55. Dimpfl, T.; Jank, S. Can internet search queries help to predict stock market volatility? Eur. Financ. Manag. 2016, 22, 171-192. [CrossRef]

56. Nyman, R.; Kapadia, S.; Tuckett, D.; Gregory, D.; Ormerod, P.; Smith, R. News and Narratives in Financial Systems: Exploiting Big Data for Systemic Risk Assessment; Bank of England Working Paper 74; Bank of England: London, UK, 2018.

57. Siganos, A.; Vagenas-Nanos, E.; Verwijmeren, P. Facebook's daily sentiment and international stock markets. J. Econ. Behav. Organ. 2014, 107, 730-743. [CrossRef]

58. Siganos, A.; Vagenas-Nanos, E.; Verwijmeren, P. Divergence of sentiment and stock market trading. J. Bank. Financ. 2017, 78, 130-141. [CrossRef]

59. Amihud, Y.; Mendelson, H. Asset pricing and the bid-ask spread. J. Financ. Econ. 1986, 17, 223-249. [CrossRef]

60. D'Avolio, G. The market for borrowing stock. J. Financ. Econ. 2002, 66, 271-306. [CrossRef]

61. Wurgler, J.; Zhuravskaya, E. Does arbitrage flatten demand curves for stocks? J. Bus. 2002, 75, 583-608. [CrossRef]

62. Baker, M.; Wurgler, J. Global, local, and contagious investor sentiment. J. Financ. Econ. 2012, 104, 272-287. [CrossRef]

63. Gao, B.; Liu, X. Intraday sentiment and market returns. Int. Rev. Econ. Financ. 2020, 69, 48-62. [CrossRef]

64. Fang, L.; Peress, J. Media coverage and the cross-section of stock returns. J. Financ. 2009, 64, 2023-2052. [CrossRef]

65. Hribar, P.; McInnis, J. Investor sentiment and analysts' earnings forecast errors. Manag. Sci. 2012, 58, 293-307. [CrossRef]

66. Frijns, B.; Verschoor, W.F.; Zwinkels, R.C. Excess stock return co-movements and the role of investor sentiment. J. Int. Financ. Mark. Inst. Money 2017, 49, 74-87. [CrossRef]

67. Ding, W.; Mazouz, K.; Wang, Q. Investor sentiment and the cross-section of stock returns: New theory and evidence. Rev. Quant. Financ. Account. 2018, 53, 493-525. [CrossRef]

68. Brigida, M.; Pratt, W.R. Fake news. N. Am. J. Econ. Financ. 2017, 42, 564-573. [CrossRef]

69. Tumarkin, R.; Whitelaw, R.F. News or noise? Internet postings and stock prices. Financ. Anal. J. 2001, 57, 41-51. [CrossRef]

70. Das, S.; Martnez-Jerez, A.; Tufano, P. e-Information: A clinical study of investor discussion and sentiment. Financ. Manag. 2005, 34, 103-137. [CrossRef]

71. Zhang, Y.; Swanson, P.E.; Prombutr, W. Measuring effects on stock returns of sentiment indexes created from stock message boards. J. Financ. Res. 2012, 35, 79-114. [CrossRef]

72. Zhang, Y.; Swanson, P.E. Are day traders bias free? Evidence from internet stock message boards. J. Econ. Financ. 2010, 34, 96-112. [CrossRef]

73. Verma, R.; Verma, P. Are survey forecasts of individual and institutional investor sentiments rational? Int. Rev. Financ. Anal. 2008, 17, 1139-1155. [CrossRef]

74. Verma, R.; Soydemir, G. The impact of US individual and institutional investor sentiment on foreign stock markets. J. Behav. Financ. 2006, 7, 128-144. [CrossRef]

75. Antoniou, C.; Doukas, J.A.; Subrahmanyam, A. Cognitive dissonance, sentiment, and momentum. J. Financ. Quant. Anal. 2013, 48, 245-275. [CrossRef]

76. Wang, Y.H.; Keswani, A.; Taylor, S.J. The relationships between sentiment, returns and volatility. Int. J. Forecast. 2006, 22, 109-123. [CrossRef] 
77. Klemola, A.; Nikkinen, J.; Peltomki, J. Changes in investors' market attention and near-term stock market returns. J. Behav. Financ. 2016, 17, 18-30. [CrossRef]

78. Lee, W.Y.; Jiang, C.X.; Indro, D.C. Stock market volatility, excess returns, and the role of investor sentiment. J. Bank. Financ. 2002, 26, 2277-2299. [CrossRef]

79. Kurov, A. Investor sentiment and the stock market's reaction to monetary policy. J. Bank. Financ. 2010, 34, 139-149. [CrossRef]

80. Teti, E.; Dallocchio, M.; Aniasi, A. The relationship between twitter and stock prices. Evidence from the US technology industry. Technol. Forecast. Soc. Chang. 2019, 149, 1-14. [CrossRef]

81. Sabherwal, S.; Sarkar, S.K.; Zhang, Y. Do internet stock message boards influence trading? evidence from heavily discussed stocks with no fundamental news. J. Bus. Financ. Account. 2011, 39, 1209-1237. [CrossRef]

82. Ng, J.; Vasvari, F.P.; Wittenberg-Moerman, R. Media coverage and the stock market valuation of TARP participating banks. Eur. Account. Rev. 2016, 25, 347-371. [CrossRef]

83. Sibley, S.E.; Wang, Y.; Xing, Y.; Zhang, X. The information content of the sentiment index. J. Bank. Financ. 2016, 62, 164-179. [CrossRef]

84. Papakyriakou, P.; Sakkas, A.; Taoushianis, Z. The impact of terrorist attacks in G7 countries on international stock markets and the role of investor sentiment. J. Int. Financ. Mark. Inst. Money 2019, 61, 143-160. [CrossRef]

85. Fong, W.M.; Toh, B. Investor sentiment and the MAX effect. J. Bank. Financ. 2014, 46, 190-201. [CrossRef]

86. Bloomberg. Bloomberg Embedded Value in Bloomberg News \& Social Sentiment Data; Technical Report Bloomberg TM; Bloomberg: New York, NY, USA, 2016.

87. González-Sánchez, M. Asymmetric causality in-mean and in-variance among equity markets indexes. N. Am. J. Econ. Financ. 2016, 36, 49-68. [CrossRef]

88. Lettau, M.; Pelger, M. Estimating latent asset-pricing factors. J. Econom. 2020, 28, 1-31. [CrossRef]

89. Onatski, A. Asymptotics of the principal components estimator of large factor models with weakly influential factors. J. Econom. 2012, 168, 244-258. [CrossRef] 